The water surplus of the Black Sea in earlier interglacials allowed Mediterranean faunas to migrate to Caucasian shores (Fedorov, 1967).

Because of the water deficit, a strong surface current flows through the Straits of Gibraltar; a bottom current of higher density flows out. The outflowing undercurrent forms a tongue into deeper Atlantic waters of equal density (Lacombe, 1961). This tongue prevents those waters from entering the Straits which are upwelling in the Canary current along the coast of Morocco and in summer time along the coast of Portugal (Krümmel, 1911).

The Pliocene is noted for a gradual decrease in temperatures. If the Mediterranean Sea at some time attained a positive water balance as other seas maintain in temperate climates, then the undertow would start to flow $E$ and would be sucking in deep waters upwelling along the Atlantic coast line. A geostrophic current akin to the one extant today would then sweep faunas as far as Sicily. Again, such an event would occur in a geologically brief period without catastrophic consequences.

A cold-water fauna in a cool Mediterranean Sea faithfully reflects ancient ocean currents and ancient water budgets and says very little about water depths which may still have been very shallow and only slowly subsiding at the time of the Pliocene transgression.

\title{
References
}

Fedorov, P. V. 1967. New data on relationships between the Paleoeuxinian and the Uzunlarian terraces on Caucasian shores of the Black Sea. Dokl. Akad. Nauk SSSR 174 (4), 924-6; AGI-Transl. pp. 69-71.

Huang, T. et al. 1972. Sedimentological evidence for current reversal at the Straits of Gibraltar. J. mar. techn. Soc. 6 (4), 25-33.

Krümmel, O. 1911. Handbuch der Ozeanographie. J. Engelhorn Nachf., Stuttgart.

Lacombe, H. 1961. Contribution à l'étude du régime du Détroit de Gibraltar. Cah. océanogr. 13 (2), 73-107.

Sylvester-Bradley, P. C. 1973. A Mediterranean catastrophe. Geol. Mag. 110, 73-4.

Department of Geology

PETER SONNENFELD

University of Windsor

Windsor, Ontario N9B 3P4,

Canada

4th June 1973

\section{Tertiary beach deposits east of Reading associated with the London Clay transgression}

SIR,-The trace fossil Ophiomorpha was described by Kennedy \& Sellwood (1970) from a sand-body believed to be of Sparnacian age, outcropping in a small pit at Knowl Hill to the E of Reading (SU 819798). In this paper the authors relied upon published sedimentological and palaeogeographic evidence in interpreting the depositional environments represented by the Reading Beds.

The Reading Beds in the $W$ of the London Basin have been conventionally interpreted as a fresh-water sequence being represented by a series of mottled red sandy clays. At their base there is a glauconitic sand facies containing Ostrea which is usually interpreted as an early Sparnacian marine transgressive deposit (Sherlock, 1962). To the W, towards London, lagoonal and fully marine sequences are developed (Wooldridge, 1926; Hester, 1965; Curry, 1965). 
An alternative explanation of the Knowl Hill sands which occur just below the London Clay is offered herein. This reappraisal has resulted from analyses of more recently published work on modern burrowers; more detailed information now available on modern near-shore environments; and my own observations.

Some of the more important literature on Ophiomorpha was reviewed in Kennedy \& Sellwood (1970) and Dike (1972). It is generally agreed amongst ichnologists that these structures were produced by callianassid crustaceans. These crustaceans are commonly found living in modern shoreface sediments where their burrows may descend for some $4 \mathrm{~m}$ into the beach (Hertweck, 1972). Biffar (1971) dealt with the detailed taxonomy of the callianassids of Florida and in more general terms with their ecology. Later work seems to suggest that these 'ghost shrimps' and their burrows are indicators of fullmarine environments ranging from the intertidal zone to depths of $700 \mathrm{~m}$. The larger species of Callianassa are, however, commonly confined to the shallowest zones of the shoreface and upper offshore (to depths of $10 \mathrm{~m}$ ). Callianassa major Say, which today produces Ophiomorpha-type burrow systems up to $4 \mathrm{~m}$ deep, is largely confined to the foreshore environments of the Georgia coast.

One vertical section from the Knowl Hill pit was presented in Kennedy \& Sellwood (1970) but it was not possible to show in this section the important lateral variations in facies which occur there, and in that paper we were primarily concerned with the description and interpretation of the Ophiomorpha burrows.

The sediments represented at Knowl Hill are of three main types:

(1) London Clay-glauconitic interlaminated sands and clays with abundant Dosiniopsis, Ditrupa and other shells $(2 \mathrm{~m}+)$.

(2) Supposed Reading Beds-current-bedded sands with rare clay drapes and Ophiomorpha at the top $(6 \mathrm{~m})$.

(3) Mottled red silty and sandy clays $(2.5 \mathrm{~m}+)$.

The mottled clays are typical of the Reading Beds elsewhere and the fossiliferous glauconitic sands and clays above the sand-body contain a fairly typical London Clay fauna. A fluvial interpretation of the supposed Reading Beds sands contains a number of anomalies. Glauconite occurs within the sands, also the overall assemblage of structures does not conform well with the expected sequence from a fluvial channel-fill. Furthermore, the presence of Ophiomorpha has to be reconciled with a supposed fluvial origin and this led Kennedy \& Sellwood (1970) to propose that the crustaceans burrowed down from the erosion surface at the base of the London Clay during the initial phases of the London Clay transgression.

As well as exhibiting trough cross-bedding, the sands also display low-angle crossbedding, flat-lamination and clay-draped current ripples. The flat-laminated sand dominates the upper part of the sequence in which the Ophiomorpha are developed (Kennedy \& Sellwood, 1970, fig. 3). While it is possible that these flat-laminated sands were the result of flood deposition (cf. McKee, Crosby \& Berryhill, 1967) the extent and thickness of this unit has always been difficult to reconcile with a fluvial interpretation. This unit is also anomalous in containing the abundant crustacean burrows. Clay-drapes on current-ripples may occur in fluvial environments, but these structures are certainly more common in nearshore marine situations (Reineck \& Wünderlich, 1968).

The basal sands do not present a completely trough cross-bedded aspect but laterally they pass into low-angle and planar cross-bedded units which, although possibly the result of point-bar accretion, more closely resemble low-angle beach accretion sets (cf. Davis et al. 1972; Wünderlich, 1972).

Rare burrows also occur in the lower parts of the sand-body. These are not of Ophiomorpha-type, but consist of large, vertical, cylindrical burrows up to $600 \mathrm{~mm}$ long and $150 \mathrm{~mm}$ in diameter. These closely resemble the burrows of the modern 'ghost crab' Ocypode, which inhabits the backshore and washover fans of the Georgia coast (Williams, 1965; Frey \& Mayou, 1971; Hill \& Hunter, 1973).

In the light of much modern work on the Sapelo area, a more satisfying interpretation of the sequence at Knowl Hill would be that the mottled sandy clays at the base represent a marsh-flat environment which was transgressed. The trough- and planar cross-bedded portion of the sand unit represent washover and backshore sands with rare crab burrows. 
The flat-bedded sand unit represents surf-zone deposition on a shoreface inhabited by callianassid crustaceans. As transgression proceeded, the shoreface was succeeded by upper offshore (Howard \& Reineck, 1972) glauconitic clay/sand laminae containing shell layers.

The implications of a possible marginal-marine facies high in the Sparnacian are considerable and would throw into doubt some of the currently held ideas on the palaeogeography of the western London Basin during the early Tertiary (cf. Wooldridge, 1926; Hester, 1965; Sherlock, 1962).

The problem now arises as to the stratigraphic affinities of the sand unit at Knowl Hill. If the above interpetation is correct, then the sands may be more conveniently considered as the basal transgressive unit of the overlying London Clay (Ypresian).

The facies change to London Clay deposition commenced with a well-documented marine transgression. It is also well known that 'Sarsens' believed to have been derived from the upper sands of the Reading Beds have a widespread distribution over the western part of the London Basin and beyond. It is interesting to note that some of the sands at Knowl Hill are irregularly cemented by calcite so that they resemble 'Sarsen' lithology.

I tentatively submit that the so-called Reading Beds sands which occur above the mottled clays both at Knowl Hill and in the vicinity of Reading should be considered as the basal transgressive member of the London Clay. Furthermore, it is possible that this facies, now represented as 'Sarsens' lying beyond the main area of Tertiary outcrop, marks the extension of the Ypresian transgression which led to the deposition of the London Clay farther E.

\section{References}

Biffar, T. A. 1971. The genus Callianassa (crustacea, decapoda, thalassin idea) in South Florida, with keys to the western Atlantic species. Bull. mar. Sci. 21, 637-715.

Curry, D. 1965. The Palaeogene Beds of South-East England. Proc. Geol. Ass. 76, $151-73$.

Davis, R. A. Fox, W. T., Hayes, M. O. \& Boothroyd, J. C. 1972. Comparison of ridge and runnel systems in tidal and non-tidal environments. J. sedim. Petrol 42, 413-21.

Dike, E. F. 1972. Ophiomorpha nodosa Lundgren: environmental implication in the Lower Greensand of the Isle of Wight. Proc. Geol. Ass. 83, 165-77.

Frey, R. W. \& Mayou, T. V. 1971. Decapod burrows in Holocene barrier island beaches and washover fans, Georgia. Senckenbergiana marit. 3, 53-77.

Hertweck, G. 1972. Georgian coastal region, Sapelo Island, U.S.A.: sedimentology and biology. V. Distribution and environmental significance of lebensspuren and in-situ skeletal remains. Senckenbergiana marit. 4, 125-67.

Hester, S. W. 1965. Stratigraphy and palaeogeography of the Woolwich and Reading Beds. Bull. geol. Surv. Gt Br. 23, 117-37.

Hill, G. W. \& Hunter, R. E. 1973. Burrows of the ghost crab Ocypode quadrata (Fabricius) on the barrier islands, South-central Texas coast. J. sed. Petrol. 43, 24-30.

Howard, J. D. \& Reineck, H. E. 1972. Georgia coastal region. Sapelo Island, U.S.A.: sedimentology and biology. IV. Physical and biogenic sedimentary structures of the nearshore shelf. Senckenbergiana marit. 4, 81-123.

Kennedy, W. J. \& Sellwood, B. W. 1970. Ophiomorpha nodosa Lundgren: a marine indicator from the Sparnacian of South-east England. Proc. geol. Ass. 81, 99-110.

McKee, E. D., Crosby, E. J. \& Berryhill, H. L. 1967. Flood deposits, Bijou Creek, June 1965. J. sedim. Pet. 37, 829-51.

Reineck, H. E. \& Wünderlich, F. 1968. Classification and origin of flaser and lenticular bedding. Sedimentology 11, 99-104.

Sherlock, R. L. 1962. British Regional Geology London and the Thames Valley. Additions by Casey, R., Holmes, S. C. A. and Wilson, V. H.M.S.O. 62 pp.

Williams, A. B. 1965. Marine decapod crustaceans of the Carolinas. Fishery Bull. 65, 1-298. 
Wooldridge, S. W. 1926. The structural evolution of the London Basin. Proc. Geol. Ass. 37, 162-96.

Wünderlich, F. 1972. Georgia coastal region, Sapelo Island, U.S.A.: sedimentology and biology. III. Beach dynamics and beach development. Senckenbergiana marit. 4, 47-79.

Oxford Polytechnic

B. W. SELLWOOD

Headington

Oxford OX3 0BP

30th May 1973

\section{On 'metabasite'}

SIR,-The term 'metabasite' first appeared in the writings of Sederholm (1907) when he stated: 'At the Geological Survey of Finland we have lately started to use the word metabasite as a general name for metamorphosed (amphibolitized) basic rocks (diabase, etc.). The term metabasite... has been suggested by Victor Hackman.' Here Sederholm says 'metamorphosed basic rocks', not 'basic metamorphic rocks', and referring as he does to 'diabase, etc.', leaves us in no doubt that metabasites are metamorphosed basic igneous rocks. Certainly, this was the sense in which the word was accepted. Rice's Dictionary of Geological Terms defines metabasite as 'A general term for metamorphosed basaltic, doleritic and allied rocks, the types included ranging from diabase and epidiorite to hornblende-schist (Holmes).' The Glossary of Geology and Related Sciences (Howell, 1957) gives 'Metabasite - a general term for metamorphosed basic igneous rocks (originated by Hackman, 1907).' The term was not widely used and Poldervaart's (1953) important review article on the metamorphism of basic rocks preferred 'metabasaltic' as a general term. Recently Miyashiro (1968) has revived 'metabasite', writing 'Metamorphic derivatives of basalt, dolerite, diabase and gabbro have been called metabasalt, metadolerite, metadiabase and metagabbro respectively. When recrystallization is essentially complete however, mafic metamorphic rocks lose all trace of the original mineralogy and texture; thus it becomes impossible to tell whether the rock was derived from basaltic or gabbroic rocks. All the metamorphosed mafic rocks have been collectively called metabasites by Finnish geologists. This term will be used in this paper.' Miyashiro scrupulously preserves and reaffirms the original sense. His practice is followed by many workers in this field.

In relation to Rosenbusch's two metamorphic prefixes, para- and ortho-, metabasites attract ortho- by definition and include ortho-amphibolites and pyroxene ortho-gneisses in the amphibolite and granulite facies respectively (see Leake, 1964).

Recently the new terms 'ortho-metabasite' and 'para-metabasite' have been coined to cover 'metabasic igneous dykes and meta-sedimentary (basic differentiates?) mafic bands associated with gneisses' (Misra, 1971). As extensions of metabasite, the terms are illogical; by definition metabasites are ortho- and they cannot also be para-. As qualifiers they are undesirable, for they virtually destroy the original meaning of metabasite by denying the term its igneous genetic connotation, moreover they introduce considerable imprecision in terms of both mineralogy and chemistry.

Up to now the definition of metabasite has been unequivocal. The new terms will lead to confusion and ambiguity. On grounds of precedence and usefulness the original definition is to be preferred.

\section{References}

Howell, J. V. 1957. Glossary of Geology and Related Sciences. American Geological Institute, Washington.

Leake, B. E. 1964. The chemical distinction between ortho- and para-amphibolites. J. Petrology 5, 238-54. 